\section{TKT infringes again}

The High Court of Justice in London has ruled that gene-activated erythropoietin (GA-EPO; Dynepo) produced by Transkaryotic Therapies (TKT; Cambridge, MA) and partner Aventis Pharmaceuticals (Bridgewater, NJ) infringes on Amgen's (Thousand Oaks, CA) multi-billion dollar red blood cell-stimulating

E drug erythropoeitin (EPO; Epogen). The o court found that GA-EPO infringes one of four claims of Amgen's European Patent (0148605B2) covering EPO and processes for making EPO, under the UK version of the US's doctrine of equivalents. The announcement, which was released on April 11 and prompted an initial $18 \%$ drop in TKT share price to $\$ 15.10$, is more bad news for TKT, which was found to infringe claims in three of Amgen's US patents in January (Nat. Biotechnol. 19, 188, 2001). TKT, which has filed for marketing authorization of Dynepo with the European Medicines Evaluation Agency, is expected to appeal this latest decision.

\section{Call for regulation of UK Human Genetics Databases}

In a report entitled Human Genetics Databases: Challenges and Opportunities, published on March 29, the UK House of Lords Science and Technology committee calls for a new Medical Data Panel to be formed to oversee regulation of personal genetics and health data. Currently, under the Data Protection Act (1998), genetic data can be used only for research specified in the donors' initial consent, and such data is often deleted before additional consent can be obtained for different studies involving the data. The new panel would devise a regulato- ry framework whereby initial consent would be broadened to allow secondary uses of genetic data while also protecting the rights and interests of participating individuals. Although researchers have welcomed the new recommendations, GlaxoSmithKline's (London) senior vice president of genetic research Allen Roses suggests that genetic databases resulting from this "opt-in" approach to informed consent may be less comprehensive than those that follow the Icelandic "opt-out" model (Nat. Biotechnol. 17, 620, 1999), ultimately dissuading large multi-national companies from conducting genetic research in the UK.

$S L$

\section{Big gift for RPI biotech}

Rensselaer Polytechnic Institute (RPI; Troy, NY) received an anonymous $\$ 360$ million donation in early March, the largest ever single donation to a US university. According to Director of Media Relations Bruce Adams, "a large portion" of the gift will go toward biotechnology and information technology programs, specifically in the areas of functional tissue engineering, integrative systems biology, biocomputation and bioinformatics, and biocatalysis and metabolic engineering. The donation was given in order to implement the "Rensselaer Plan", an initiative created in 2000 by RPI President Shirley Jackson to increase the overall research budget from $\$ 40$ million to $\$ 100$ million, double graduate enrollment by 2005 , and expand its Business Incubator Program in which faculty and students receive university support to start their own company based on individual research. The expansions include new programs and classes in entrepreneurship, business management, and intellectual property strategies.

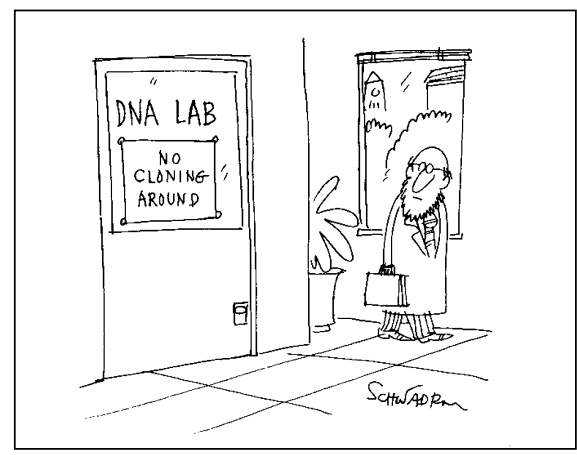

\section{California needs more power}

At least two California biotech firms have warned investors that the state's power problems could hamper production and affect their bottom line. The bankruptcy of California's largest electrical utility company on April 5 underscored the state's ongoing energy crisis (Nat. Biotechnol. 18, 1127, 2000), which is expected to only worsen during the summer months. Idec Pharmaceuticals (San Diego, CA) stated in early April that temporary power losses have threatened production of the firm's monoclonal antibody, Zevalin; diagnostic kit-maker Quidel (San Diego, CA) said the energy problems could "damage our reputation, harm our ability to retain existing customers, and result in lost revenue." Meanwhile, in a more general response to the nation's energy crisis, the Biotechnology Industry Organization (Washington, DC) is drafting legislation to present to the Bush administration for federally funded research into the use of biomass energy sources that use bioengineered enzymes as a way of increasing energy supplies.

\begin{tabular}{lll}
\multicolumn{2}{l}{ Research Collaborations } & \\
Company 1 & Company 2 & \$(Million \\
\hline $\begin{array}{l}\text { Millennium } \\
\text { Pharmaceuticals } \\
\text { (Cambridge, MA) }\end{array}$ & $\begin{array}{l}\text { Abbott } \\
\text { Laboratories } \\
\text { (Abbott Park, IL) }\end{array}$ & 250 \\
& \\
$\begin{array}{l}\text { Epigenesis } \\
\text { (Cranbury, NJ) }\end{array}$ & $\begin{array}{l}\text { Taisho } \\
\text { (Tokyo) }\end{array}$ \\
$\begin{array}{l}\text { X-Ceptor } \\
\text { (San Diego, CA) }\end{array}$ & $\begin{array}{l}\text { Sankyo } \\
\text { (Tokyo) }\end{array}$ \\
& \\
& \\
& \\
Diversys & \\
(Cambridge, UK) & $\begin{array}{l}\text { Peptech } \\
\text { (North Ryde, } \\
\text { Australia) }\end{array}$ & \\
&
\end{tabular}

